\title{
KARAKTERISTIK REKAHAN PADA BATUAN DASAR DI BLOK JABUNG, SUB- CEKUNGAN JAMBI, SUMATRA SELATAN
}

\author{
KIDDY NAHLI AULIA, BENYAMIN SAPIIE \\ Program Studi Teknik Geologi, Fakultas Ilmu dan Teknologi Kebumian, Institut Teknologi Bandung \\ (ITB), Jl. Ganesha No.10, Bandung, Jawa Barat, Indonesia. Email: kiddynahli@gmail.com
}

\begin{abstract}
Sari - Cekungan Sumatra Selatan merupakan cekungan yang memiliki batuan dasar terekahkan penghasil gas yang cukup berhasil. Batuan dasar di Blok Jabung Sub-Cekungan Jambi memiliki potensi untuk menjadi reservoir pada batuan dasar terekahkan. Saat mengidentifikasi reservoir batuan dasar terekahkan, harus dilakukan identifikasi dari karakteristik rekahan tersebut, karena hidrokarbon pada batuan dasar akan terkonsentrasi pada rekahan yang membuat batuan dasar tersebut memiliki porositas rekahan yang baik. Karakteristik rekahan yang akan dikaji adalah tingkat intensitas rekahan, densitas rekahan dan porositas rekahan pada 2 sumur pemboran di daerah penelitian, dengan beberapa rentang kedalaman yang ditentukan. Rentang kedalaman yang berbeda akan memperlihatkan hasil yang berbeda pula. Nilai intensitas, densitas, dan porositas rekahan tidak selamanya memiliki puncak pada kedalaman yang sama, dikarenakan beberapa faktor yang mempengaruhi seperti luas rekahan dan ketebalan rekahan. Porositas rekahan akan menjadi hal yang menarik karena porositas merupakan salah satu syarat untuk menjadi reservoir.
\end{abstract}

Kata kunci: Karakteristik rekahan, batuan dasar, reservoir terekahkan, porositas rekahan

\begin{abstract}
South Sumatra Basin is a basin which success enough to produce gas in fractured reservoir. Basement rock in Jabung Block, Jambi Sub-Basin has a potention to be a fractured reservoir. Identifying basement fractured reservoir, it has to identify characterization of fractures, because hydrocarbon will acummulate in there, and make a abasement rock has porosity. Fracture characterization that will be studied are fracture intensity, fracture density, and fracture porosity in 2 wells at study area, with several determined depth range. Different depth range will show a different result. High value of intensity, density, and porosity don't always refer to same dept. It because of several factors such as area of fractures and apperture of fractures. Fracture porosity will be an interesting point because it is one of terms to a reservoir.
\end{abstract}

Keywords: Fracture characterization, basement rock, fractured reservoir, fracture porosity

\section{INTRODUCTION}

Cekungan Sumatra Selatan merupakan cekungan batuan dasar terekahkan penghasil gas yang cukup berhasil, seperti pada Lapangan Suban. Batuan dasar di Blok Jabung Sub-Cekungan Jambi pun memiliki potensi untuk menjadi reservoir pada batuan dasar terekahkan, karena memiliki sejarah tektonik yang tidak jauh berbeda dengan Lapangan Suban. Saat mengidentifikasi reservoir batuan dasar terekahkan, harus dilakukan identifikasi dari karakteristik rekahan tersebut, karena hidrokarbon pada batuan dasar akan terkonsentrasi pada rekahan yang membuat batuan dasar tersebut memiliki porositas dan permeabilitas. Karakteristik rekahan berupa intensitas rekahan, densitas rekahan, dan porositas rekahan akan menjadi sangat penting untuk memahami karakter dari rekahan - rekahan yang ada di daerah penelitian. Daerah penelitian berada pada Blok Jabung Sub-Cekungan Jambi (Gambar 1). Secara fisiografi, Cekungan Sumatra Selatan dibatasi oleh Tinggian Tigapuluh di utara, Pulau Bangka di sebelah timur, Pegunungan Bukit Barisan di bagian barat dan baratdaya, dan Tinggian Lampung di bagian selatan dan tenggara (Barber, 2005). Batuan dasar pada daerah ini merupakan granit yang telah mengalami beberapa proses tektonik, sehingga sangat berpotensi memiliki rekahan yang relatif terbuka (Suta, 2003). Terdapat 2 sumur yang diharapkan dapat menjelaskan karakteristik rekahan di daerah penelitian. 


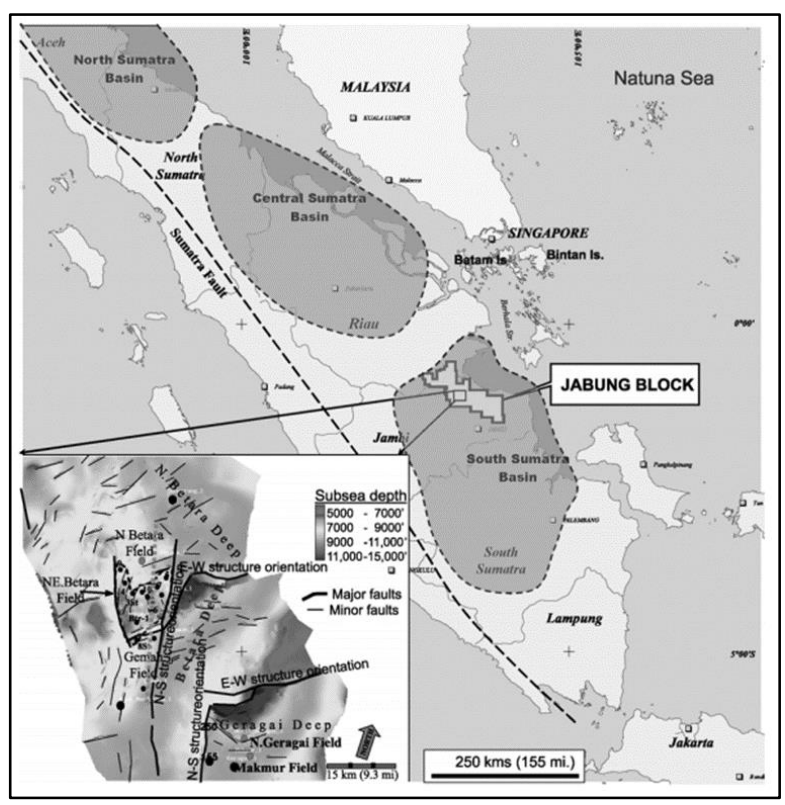

Gambar 1. Lokasi daerah penelitian pada Cekungan Sumatra Selatan dan Blok Jabung (Suta, 2003).

\section{DATA AND METODOLOGI}

\subsection{Data}

Data yang digunakan pada penelitian ini adalah data log gambar. Kenampakan rekahan alami pada log gambar akan berbentuk sinusoidal, karena hasil dari log gambar merupakan sisi dari tabung yang dibuka. Rekahan yang teridentifikasi adalah rekahan konduktif, resistif, dan gabungan. Rekahan konduktif merupakan rekahan yang terbuka kembali akibat adanya lumpur pemboran, dan bersifat konduktif ketika dibaca oleh log gambar. Rekahan resistif rekahan tertutup yang sudah terisi oleh mineral atau urat, sehingga rekahan ini bersifat resistif ketika dibaca oleh log gambar. Rekahan gabungan merupakan kombinasi rekahan konduktif dan resistif.

\subsection{Metodologi}

Karakteristik rekahan setiap sumur dapat dilihat dari kumpulan arah azimut dan kemiringannya dalam bentuk histogram. Rekahan dalam sumur pemboran akan dihitung intensitas rekahan, densitas rekahan, dan porositas rekahan. Intensitas merupakan jumlah rekahan yang muncul dalam rentang yang ditentukan. Dalam penelitian ini rentang yang digunakan adalah $1 \mathrm{ft}, 10 \mathrm{ft}$ dan $100 \mathrm{ft}$.
Intensitas rekahan (Naar, dkk., 2006) dalam sumur pemboran dapat didefinisikan dengan rumus sebagai berikut:

$$
\begin{gathered}
I_{f}=\frac{N}{h_{r}} \\
V_{r}=\pi\left(\frac{D}{2}\right)^{2} h_{r} \\
d_{f}=\frac{\sum_{i=1}^{n_{f}} A_{f i}}{V_{r}}=\frac{\sum_{i=1}^{n_{f}} h_{f i}}{D h_{r}} \\
\emptyset_{f}=\frac{\sum_{i=1}^{n_{f}} a_{f i} A_{f}}{V_{r}}=\frac{\sum_{i=1}^{n_{f}} a_{f i} h_{f i}}{D h_{r}}
\end{gathered}
$$

$I_{f}$ merupakan intensitas rekahan, yaitu jumlah rekahan yang muncul $(N)$ dalam rentang kedalaman yang di tentukan $\left(h_{r}\right)$. Densitas rekahan $\left(d_{f}\right)$ merupakan luas dari rekahan yang berbentuk oval $\left(A_{f i}\right)$ dibagi volume rekahan yang berbentuk tabung $\left(V_{r}\right)$. Porositas rekahan adalah volume dari rekahan dibagi volume dari tabung. Volume rekahan sendiri merupakan luas rekahan yang berbentuk oval dikali dengan tebal rekahan atau apertur $\left(a_{f i}\right)$. Ketebalan rekahan diukur secara manual melalui perangkat lunak dengan memperhitungkan ketebalan semu dan kemiringan dari rekahan tersebut. Rentang kedalaman yang akan dikaji adalah per $1 \mathrm{ft}$, per $10 \mathrm{ft}$, dan per $100 \mathrm{ft}$.

\section{HASIL}

\subsection{Karakteristik Rekahan di Well-1}

Rekahan alami pada well-1 diidentifikasi menggunakan log gambar pada interval kedalaman 4983' - 8269' ft MD. Total rekahan alami yang teridentifikasi sebanyak 516 rekahan. Rekahan yang teridentifikasi dapat dibagi menjadi 3, yaitu rekahan konduktif, resistif dan gabungan. Rekahan konduktif merupakan rekahan yang terbuka dan terisi oleh lumpur pemboran, sehingga ketika dibaca 

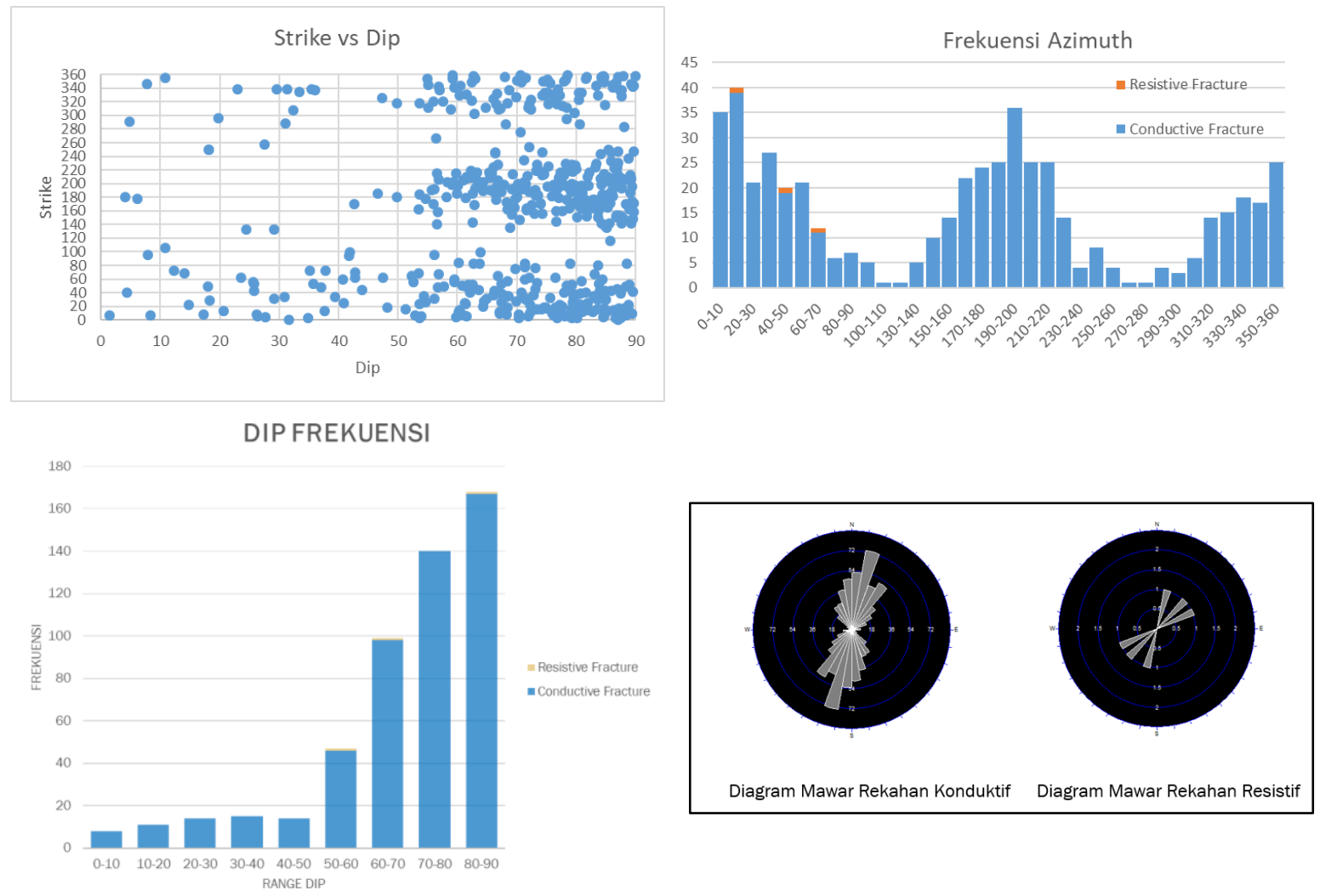

Gambar 2. Histogram azimuth, dip, dan diagram mawar dari rekahan pada well-1.

oleh log gambar akan bersifat konduktif. Rekahan resistif merupakan rekahan yang tertutup. Rekahan ini sudah terisi oleh mineral, sehingga ketika dibaca oleh log gambar akan bersifat resistif, sedangkan rekahan gabungan merupakan gabungan antar rekahan konduktif dan resistif. Rekahan konduktif teridentifikasi paling dominan sebanyak 513 rekahan, sedangkan rekahan resistif sebanyak 3 rekahan, namun rekahan gabungan tidak teridentifikasi pada sumur ini. Histogram untuk arah jurus menunjukan arah dominan $\mathrm{N} 10-20^{\circ} \mathrm{E}$ dan $\mathrm{N}$ $190-200^{\circ} \mathrm{E}$, sedangkan besaran dip didominasi oleh kemiringan yang curam yaitu $80^{\circ}-90^{\circ}$ (Gambar 2). Pada diagram mawar, rekahan konduktif menunjukan arah utara timurlaut selatan baratdaya, sedangkan rekahan resistif menunjukan arah timurlaut - barat daya (Gambar 2).

Intensitas rekahan dilihat dengan mengunakan persamaan (1). Hasil analisis grafik dapat dilihat pada Gambar 3, dan dapat disimpulkan bahwa rata-rata rekahan yang muncul yaitu
1.78 rekahan per ft, namun karena datanya cukup tersebar, maka cukup sulit melihat pada kedalaman yang mana yang memiliki intensitas rekahan yang tinggi, sehingga dilihat pula pada rentang per $10 \mathrm{ft}$ dan per $100 \mathrm{ft}$. Terlihat dari kedua grafik tersebut bahwa kedalaman sumur yang memiliki intensitas rekahan yang tinggi terdapat pada kedalaman 6200' - 6400'.

Kemudian perhitungan untuk densitas dan porositas pada rekahan - rekahan tersebut dengan menggunakan Persamaan (2) dan (3) untuk melihat persebaran luas dan volume rekahan, serta kedalaman yang memiliki porositas rekahan yang tinggi. Hasil perhitungan dapat dilihat pada Gambar $\mathbf{4}$ dan 5. Puncak kedalaman yang memiliki densitas dan porositas rekahan memiliki puncak yang relatif sama, yaitu di sekitar kedalaman 6200' dan 6400' MD. Kedua kedalaman tersebut memiliki porositas rekahan sekitar $1.1 \%$. 
Terdapat puncak-puncak intensitas, densitas, dan porositas rekahan yang berbeda pada setiap sumur. Hal ini dikarenakan intensitas rekahan hanya sekedar menghitung jumlah kemunculan rekahan, sedangkan densitas rekahan merupakan luas dari rekahan tersebut, dan juga porositas rekahan yang dipengaruhi oleh besarnya aperture dari setiap rekahan. Maka dari itu, sangat mungkin ditemukan kedalaman yang memiliki intensitas rekahan yang tinggi, porositas rekahan yang rendah, begitu juga sebaliknya. Seperti pada kedalaman 6400', yang memiliki intensitas rekahan tertinggi, yaitu lebih dari 50 rekahan per $100 \mathrm{ft}$, namun densitas rekahan bukan yang tertinggi, namun ketiga tertinggi, yaitu $4 f t^{2} / f t^{3}$, dan porositas rekahannya sebesar $1 \%$. Densitas tertinggi berada pada kedalaman 6200' dengan nilai 5 $f t^{2} / f t^{3}$ dan porositas tertingginya sebesar $1.1 \%$. namun memiliki densitas rekahan dan
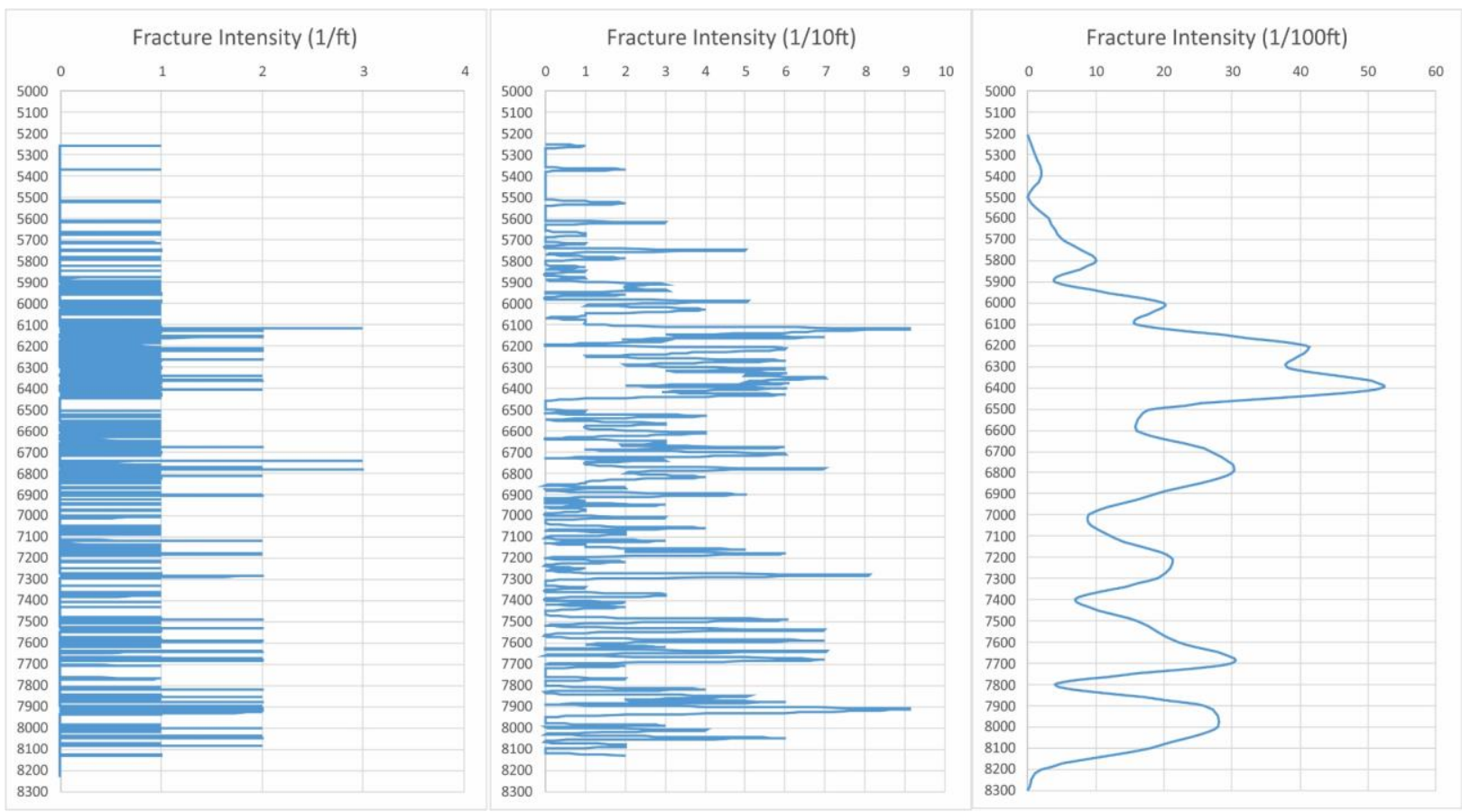

Gambar 3. Grafik intensitas rekahan per $1 \mathrm{ft}$ (kiri), per $10 \mathrm{ft}$ (tengah) dan per $100 \mathrm{ft}$ (kanan) pada well-1. 

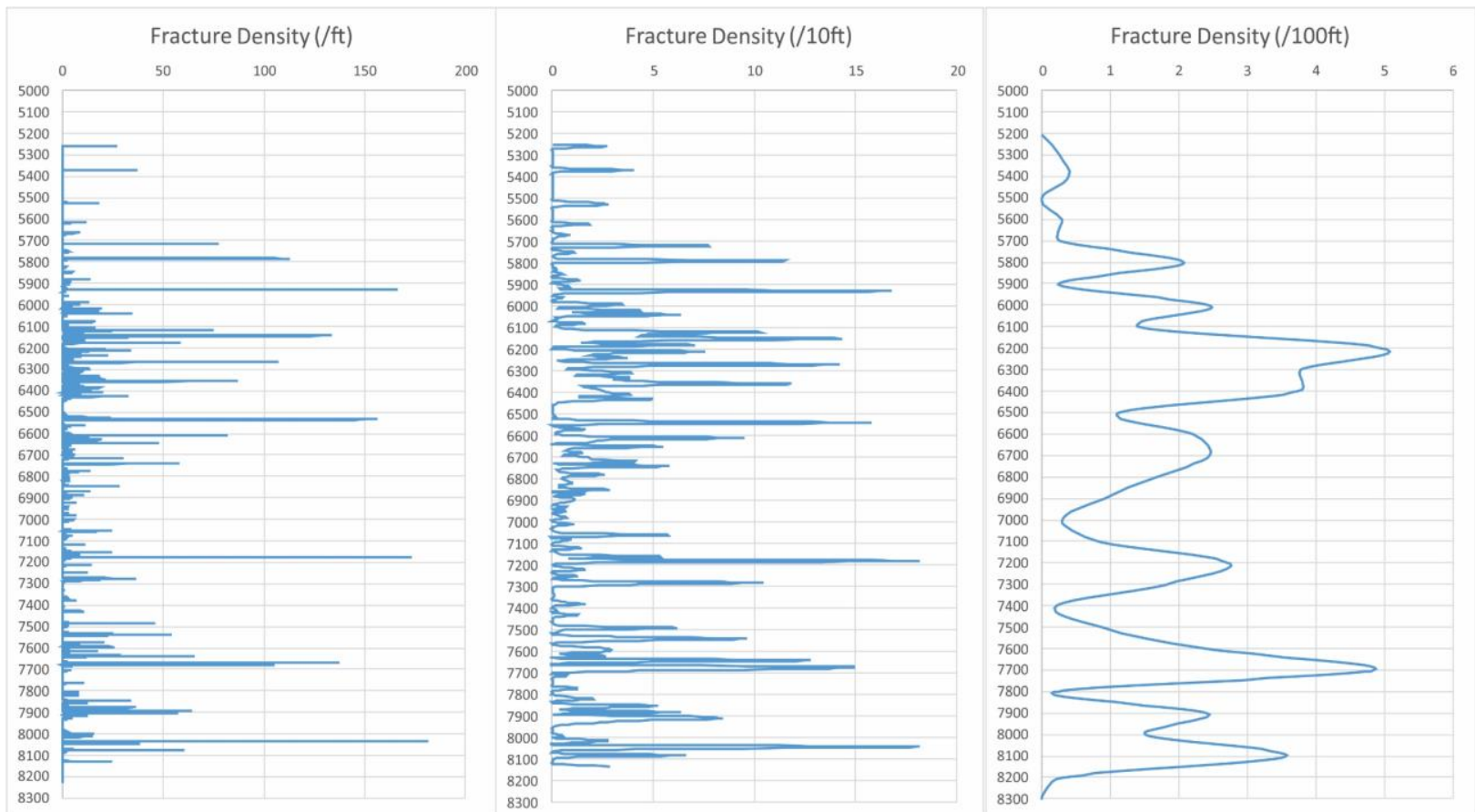

Gambar 4. Grafik densitas rekahan per $1 \mathrm{ft}$ (kiri), per $10 \mathrm{ft}$ (tengah) dan per $100 \mathrm{ft}$ (kanan) pada well-1.
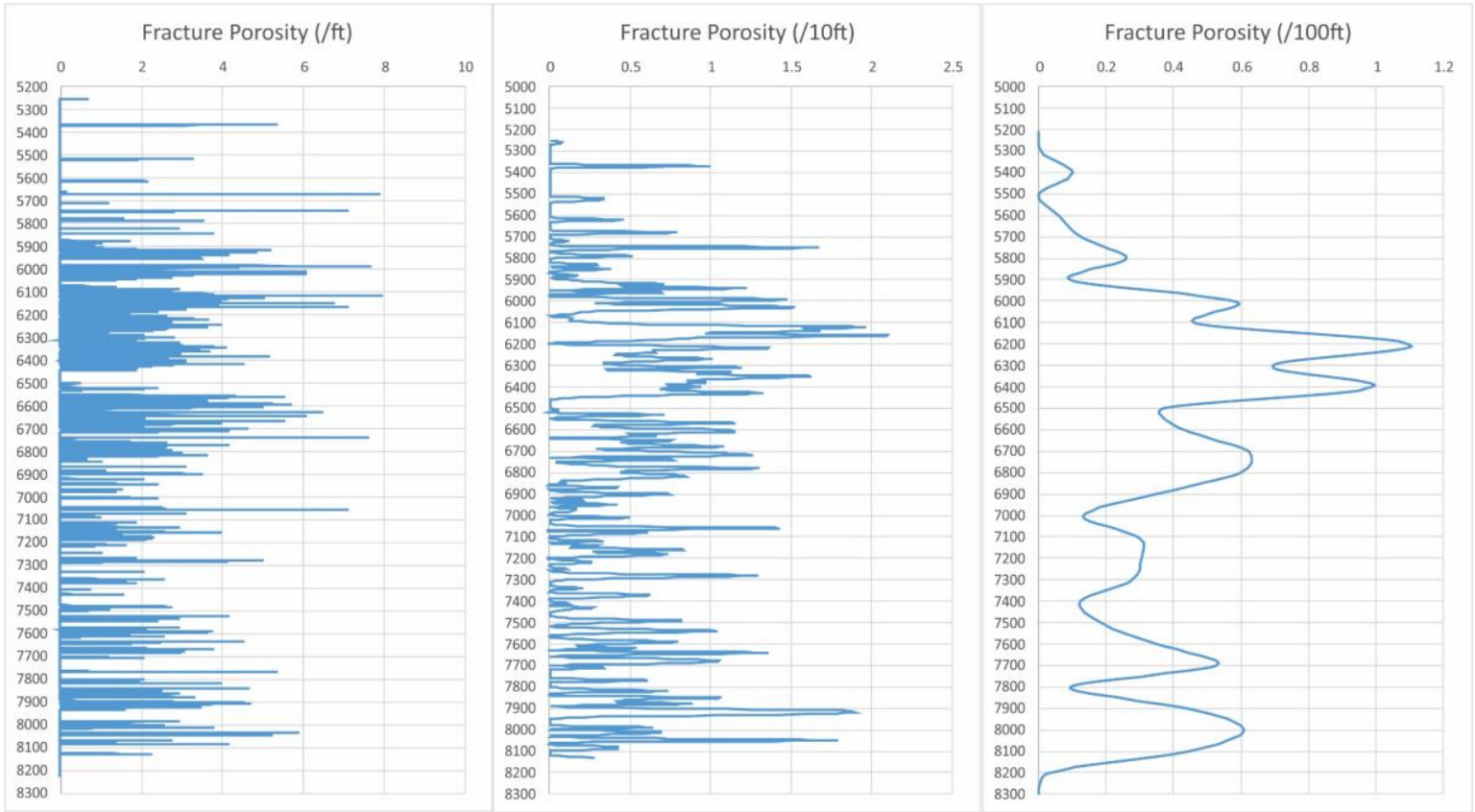

Gambar 5. Grafik porositas rekahan rekahan per $1 \mathrm{ft}$ (kiri), per $10 \mathrm{ft}$ (tengah) dan per 100 $\mathrm{ft}$ (kanan) pada well-1. 


\subsection{Karakteristik Rekahan Well-2}

Rekahan alami pada well-2 diidentifikasi menggunakan log gambar pada interval kedalaman 6578' - 8882' ft MD. Total rekahan alami yang teridentifikasi sebanyak 543 rekahan. Rekahan konduktif teridentifikasi paling dominan sebanyak 515 rekahan, sedangkan rekahan resistif sebanyak 21 rekahan, dan rekahan campuran sebanyak 7 rekahan. Histogram arah jurus menunjukan arah dominan $180-190^{\circ}$ dan 220-230 sedangkan besaran dip didominasi oleh kemiringan yang curam yaitu $70-80^{\circ}$ (Gambar 6). Kemiringan yang agak curam dan curam ini sangat umum dijumpai pada struktur sesar mendatar, dikarenakan rekahan secara dominan akan muncul dengan arah tegak lurus terhadap tegasan yang paling kuat atau maksimum, dan dalam hal sesar mendatar, tegasan maksimumnya memiliki arah horizontal, sehingga arah rekahannya cenderung vertikal. Pada diagram mawar, rekahan konduktif menunjukan arah yang beragam, yaitu utara - selatan, utara baratlaut selatan tenggara, dan utara timurlaut - selatan baratdaya. Hal ini menunjukan bahwa di well2 memiliki rekahan yang diakibatkan oleh beragamnya struktur lokal di sekitar well-2. Sesar yang berada di sekitar well-2 merupakan sesar normal (Gambar 1) yang telah mengalami proses reaktivasi, namun tidak terlalu signifikan, sehingga tegasan yang ada bekerja pada rekahan yang lebih beragam. Diagram mawar pada rekahan resistif menunjukan arah utara timurlaut - selatan baratdaya, dan rekahan campuran menunjukan arah timurlaut - baratdaya (Gambar 6).

Pada sumur ini, nilai intensitas rekahan (Gambar 7) yang tinggi tidak selalu menunjukan densitas rekahan dan porositas rekahan yang tinggi. Variasi puncak pada intensitas rekahan memiliki puncakan yang beragam. Berbeda dengan densitas rekahan yang memiliki puncakan yang mencolok, yaitu pada kedalaman 7000' dengan densitas rekahan hampir $12 f t^{2} / f t^{3}$. Hal ini menunjukan bahwa, rekahan - rekahan yang memiliki tingkat intensitas rekahan yang tinggi tidak selalu memiliki luas yang besar, seperti pada kedalaman 8100' - 8200' yang hanya memiliki densitas rekahan sebesar $4 \mathrm{ft}^{2} / f t^{3}$ (Gambar 8). Porositas rekahan pada sumur ini justru memiliki kedalaman yang relatif sama dengan intensitas rekahan yaitu pada kedalaman 6900' - 7000', 8100' - 8200' dan 8400 ' - 8500', dengan porositas sekitar 1.1 $1.2 \%$ (Gambar 9). Hal ini sangat dipengaruhi oleh aperture atau ketebalan dari rekahan pada kedalaman - kedalaman tersebut yang memiliki ketebalan yang cukup tebal, sehingga memiliki volume rekahan yang relatif lebih besar.

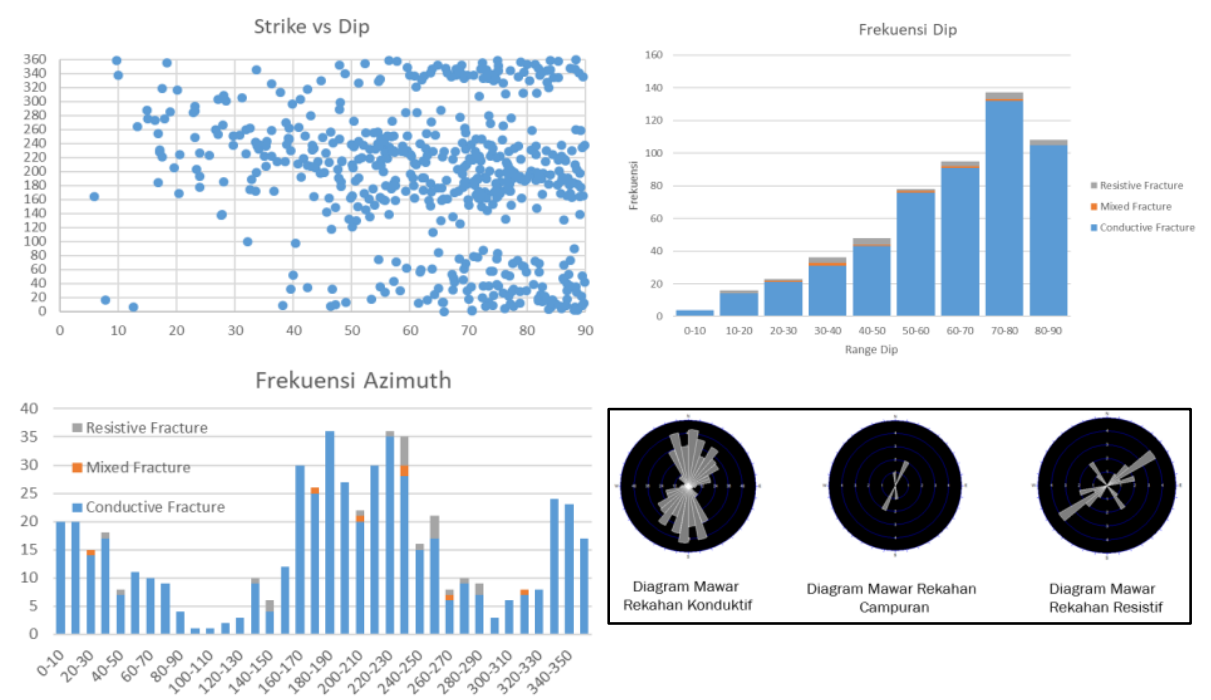

Gambar 6. Histogram azimuth, dip, dan diagram mawar dari rekahan pada well-2. 

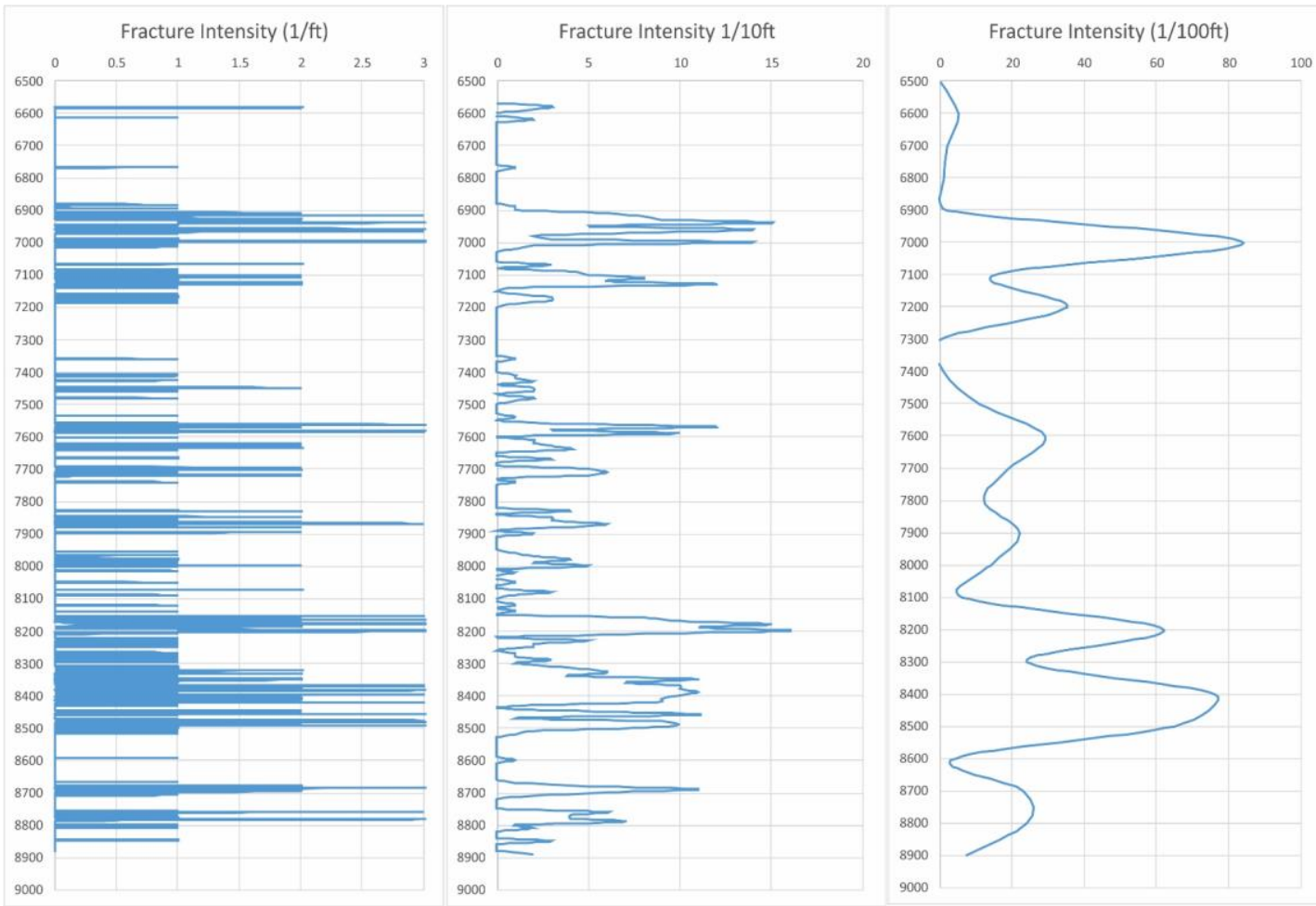

Gambar 7. Grafik intensitas rekahan rekahan per $1 \mathrm{ft}$ (kiri), per $10 \mathrm{ft}$ (tengah) dan per 100 $\mathrm{ft}$ (kanan) pada well-2.

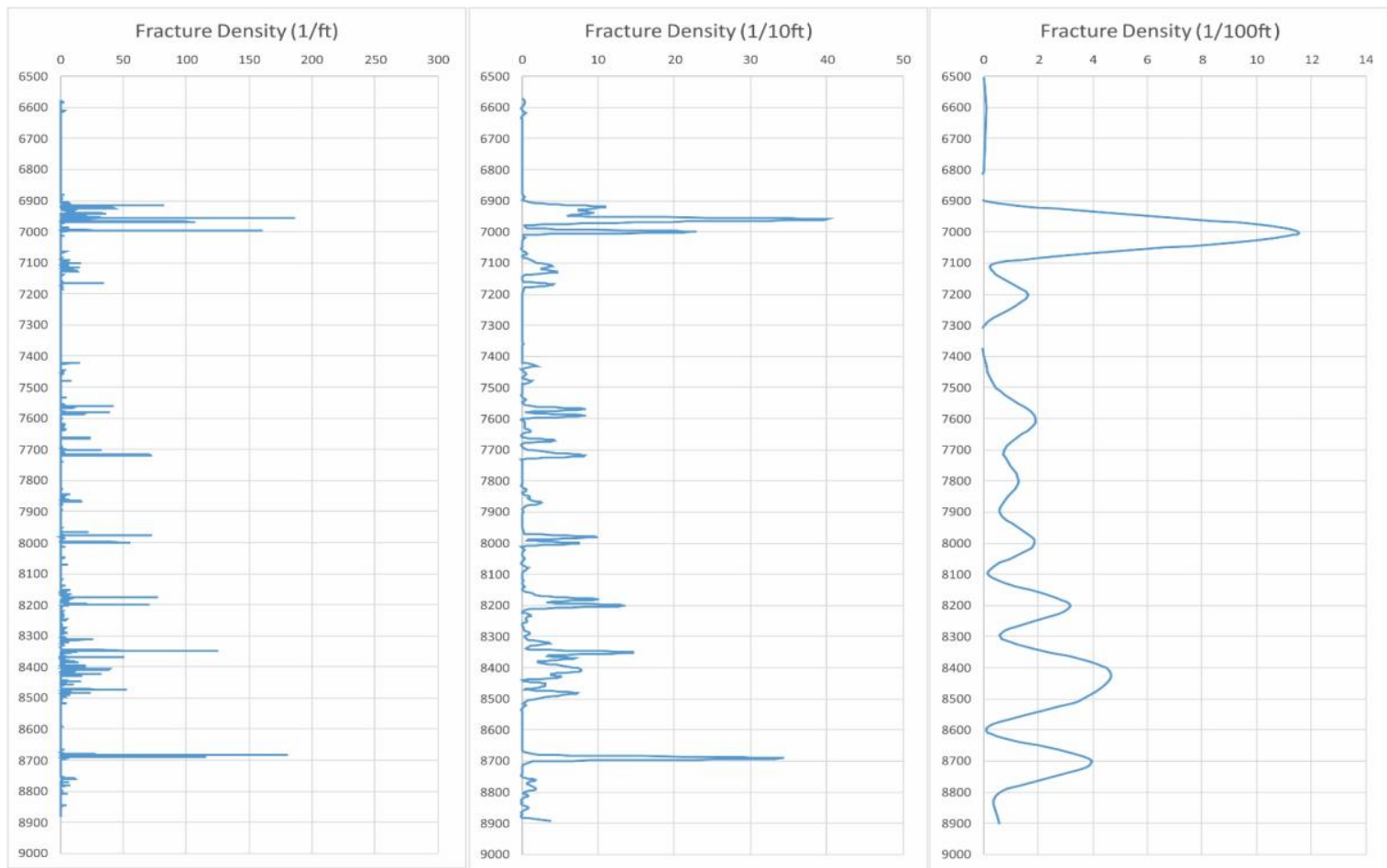

Gambar 8. Grafik densitas rekahan rekahan per $1 \mathrm{ft}$ (kiri), per $10 \mathrm{ft}$ (tengah) dan per $100 \mathrm{ft}$ (kanan) pada well-2. 

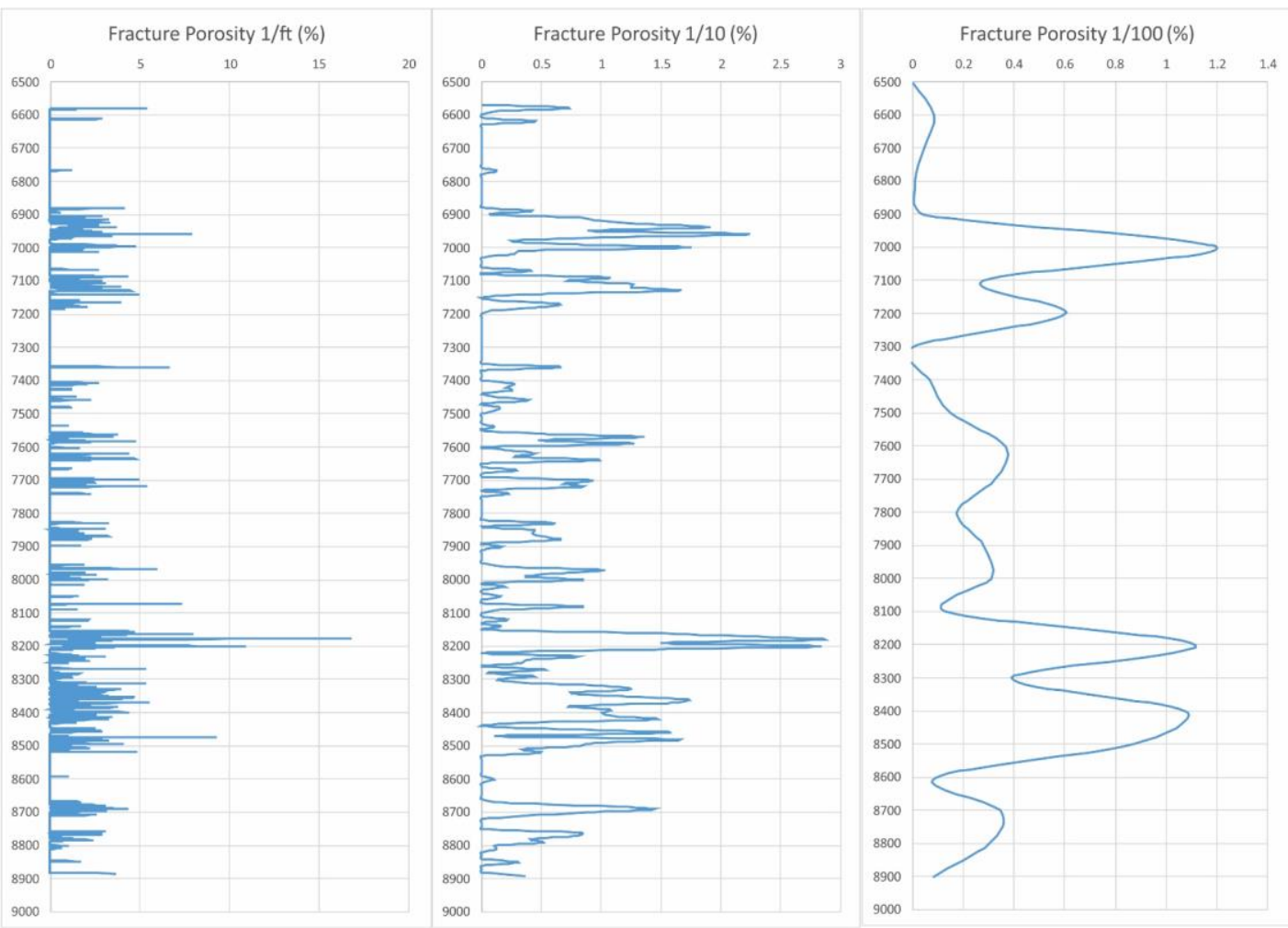

Gambar 9. Grafik densitas rekahan rekahan per $1 \mathrm{ft}$ (kiri), per $10 \mathrm{ft}$ (tengah) dan per 100 $\mathrm{ft}$ (kanan) pada well-2.

\section{KESIMPULAN}

Terdapat beberapa zona porositas rekahan yang tinggi pada well- 1 yaitu pada kedalaman 6200', 6400' dan 6700' MD, sedangkan pada well-2 yaitu pada kedalaman 7000', 8200' dan 8400 ' MD. Nilai intensitas rekahan yang tinggi tidak selalu menunjukan densitas rekahan dan porositas rekahan yang tinggi, hal ini dikarenakan intensitas rekahan hanya mempertimbangkan jumlah, sedangkan densitas rekahan mempertimbangkan luas rekahan, sehingga akan muncul rekahan yang memiliki intensitas rekahan yang kecil namun memiliki densitas rekahan yang tinggi. Begitu pula dengan porositas rekahan yang dipengaruhi oleh tebal atau apertur dari rekahan tersebut.

\section{ACKNOWLEDGMENT}

Penulis mengucapkan terimakasih kepada PetroChina International Jabung Ltd..

\section{DAFTAR PUSTAKA}

Barber, A. J. (2005): Sumatra: Geology, resource and tectonic evolution, Geological Sociey Memoirs No 31, London.

Narr, W., Schechter, S. S., dan Thompson, L. B. (2006): Naturally fractured reservoir characterization, Society of Petroleum Engineer, USA

Suta, I. N. (2003): Reservoir characterization of Lower Talang Akar fluvial sandstones, Northeast Betara (NEB) field, South Sumatra Basin, Thesis Master, University of Oklahoma. 